\title{
Just Another House Call
}

Glenn D. Miller, MD

It was no different from any other first Wednesday of the month. I checked my patients at the hospital, did some administrative work at the medical school, and set out to make house calls. I have always felt a special bond with my patients from Bradford. Since leaving this small town in central Illinois to teach at the local medical school, I have continued to provide home visits to those patients who could not travel to my new office 35 miles away. House calls provide a valued extra for both the patient and me.

She was my last call of the day. Though she was 89 years of age, she was still feisty, but slowly withering. Before this particular day in March, she called and was concerned that I had not seen her in the expected 4 months.

When I arrived, I could hear the television blaring from outside the residence. A knock on the door did not lead to the customary response. As I peered into the window, I saw her watching television and reading a book. I rang the doorbell without reaction.

Knowing of her presbycusis, I attempted to call her using my cell phone. After the 20th ring, I hung up. Peering back into the window, I discovered she was no longer sitting in her easy chair. She had noticed my presence in her driveway and motioned me to come in.

I explained my dilemma, and she explained that a salesman examined her and told her she needed new hearing aides. She questioned him about her recent acute loss of hearing, but after his expert examination, he reassured her it was not secondary to wax. She had delayed the purchase, not wanting to part with her son's inheritance.

Submitted, revised, 29 May 1999.

From the Department of Family and Community Medicine, University of Illinois College of Medicine at Peoria. Address reprint requests to Glenn D. Miller, MD, Department of Family and Community Medicine, University of Illinois College of Medicine at Peoria, Box 1649, Peoria, IL 61656-1649.
After addressing her hypertension, coronary artery disease, and chronic constipation, I offered to exclude the possibility of cerumen. Reluctantly, she agreed. Upon my examination, I noted the massive amount of impacted varnish that occluded her otic canals.

After I flushed her otic canals with a bit of warm tap water, I was able to remove the golden brown nuggets, and the patient exclaimed, "Golly, I guess I don't need new hearing aides."

At the end of my visit, we discussed her future. She had twice before declined stress testing, cardiac catheterization, and lower gastrointestinal endoscopy. Her goals were clear. She wished to do as well as she could, for as long as she could, without high-tech intervention.

Often I question the overall benefits of the technological advancements that have occurred in the 16 years since I was graduated from medical school. $\mathrm{We}$, as a society, value complexity rather than simple utility. We often forget the true desires of the patient in our efforts to provide the "standard of care."

On this March day I cured deafness rather than coronary artery disease and went home satisfied with the outcome.

Reflecting on this house call, my feelings about its extra value are strengthened. The home visit allows me to evaluate the patient within the patient's environment. By doing so, I experience a role reversal; I become the guest and the patient becomes the host. The lack of comprehensive examination facilities is offset by the patient being at ease with the surroundings. Often I gain a broader insight into the patient's activities of daily living.

During this home visit, I appreciated with greater intensity the impact of this patient's medical problems on her ability to function independently. The hearing loss was clearly apparent; she could not hear the doorbell or the telephone ring. I might have missed the severity of the loss at my 
office. Because she desired limited interventions, the visit also gave my patient an opportunity to obtain medical care that was suited to her wishes.
Within my clinical practice, house calls will always be fulfilling experiences that bring added value to my physician-patient relationship. 